\title{
o4. Yabancılara Türkçe öğretimi alanında ek çalışma kâğıtları ile deyim öğretimi
}

Mesut GÜN1

Lokman TANRIKULU²

Aslıhan TÜRK3

\begin{abstract}
APA: Gün, M.; Tanrıkulu, L.; Türk, A.. (2021). Yabancılara Türkçe öğretimi alanında ek çalışma kâğıtları ile deyim öğretimi. RumeliDE Dil ve Edebiyat Araştırmaları Dergisi, (23), 49-64. DOI: 10.29000/rumelide.948289.
\end{abstract}

\section{$\ddot{\mathbf{O} z}$}

Deyimler bir milletin tarihî geçmişini, yaşayış tarzını, maddi ve manevi kültürel değerlerini yansıtan söz varlı̆̆ıdır. Deyimler, yabancı dil olarak Türkçe öğretimi alanında ehemmiyeti yüksek bir konudur. Bir milletin dilini öğrenmek aslında o dile ait kalıp ifadelerin doğru kullanımı ile mümkündür. Sağlıklı ve düzgün bir iletişimin gerçekleşmesi için de söz varlığımız olan deyimlerin yabancı dil olarak Türkçe öğretimi alanında öğrenilmesi ya da doğru öğretilmesi önem arz etmektedir. Bu çalışmada yabancı dil olarak Türkçe öğretimi alanında öğrencilere sunulan ek çalışma kâğıtları ile deyim öğretiminin etkili ve kalıcı olabilme yollarını belirlemek esas alınmıştır. Çalışma kâğıtlarında deyimi tahmin etmeye ve somutlaştırmaya yönelik görseller kullanılmış, daha sonra deyim hikâyesi ile birlikte metin içerisinde anlatılmıştır. Deyimlerin hikâyesi İskender Pala’nın ‘İki Dirhem Bir Çekirdek’ kitabından alınmıştır. Deyim öğretiminde kitapta yer alan 100 deyimden sadece dokuz tanesi üzerinde uzman görüşlerinden hareketle çalışma kâğıtları geliştirilmiştir. Bu araştırmada doküman analizi yöntemi kullanılmıştır. Araştırmanın sonunda deyimlerin öğretimi hususunda yapılacak etkinliklerin ve ek çalışma kâğıtlarının daha etkili ve kalıcı öğrenmelere hizmet edebileceği tespit edilmiştir. Öğrenme eyleminin sadece sınıf içinde değil de günlük hayatta ve okul dışında da devam ettiği ulaşılan bulgulardandır. Öğrencinin sürece aktif katılımı ve bu şekilde takip edilmesi dil öğretimi açısından bir gereklilik arz etmektedir. Elde edilen bulgular bundan sonra yapılacak benzer çalışmalara örnek olabilecek niteliktedir.

Anahtar kelimeler: Yabancı dil olarak Türkçe öğretimi, deyimler, ek çalışma kâğıtları

\section{Teaching idioms with supplementary worksheets in teaching Turkish to foreigners}

\begin{abstract}
Idioms are lexical items that reflect the historical background, lifestyle, material and spiritual cultural values of a nation. Idioms are a subject of high importance in the field of teaching Turkish as a foreign language. Learning the language of a nation is possible with the correct use of the
\end{abstract}

Doç. Dr., Mersin Üniversitesi, Eğitim Fakültesi, Türkçe ve Sosyal Bilgiler Eğitimi Bölümü, Türkçe Eğitimi ABD (Mersin, Türkiye), mesutgun@mersin.edu.tr, ORCID ID: oooo-0001-9663-1066 [Araştırma makalesi, Makale kayıt tarihi: 23.02.2021-kabul tarihi: 20.06.2021; DOI: 10.29000/rumelide.948289]

Doç. Dr., Nevşehir Hacı Bektaş Veli Üniversitesi, Eğitim Fakültesi, Yabancı Diller Eğitimi Bölümü, Alman Dili Eğitimi ABD (Nevşehir, Türkiye), ltanrikulu@nevsehir.edu.tr, ORCID ID: 00oo-0002-1862-8176

3 YL Öğrencisi, Nevşehir Hacı Bektaş Veli Üniversitesi, Sosyal Bilimler Enstitüsü, Türkçe Eğitimi ABD (Nevşehir, Türkiye), aslihan.turk42@gmail.com, ORCID ID: oooo-0003-4709-457X

Adres $\mid$ Address

RumeliDE Dil ve Edebiyat Araşttrmalar Dergisi $\quad$ RumeliDE Journal of Language and Literature Studies Osmanağa Mahallesi, Mürver Çiçeği Sokak, No:14/8 Osmanağa Mahallesi, Mürver Çiçeği Sokak, No:14/8

Kadıköy - İSTANBUL / TÜRKIYE 34714 Kadıköy - ISTANBUL / TURKEY 34714 e-posta: editor@rumelide.com

e-mail: editor@rumelide.com,

tel: +90 505 7958124, +90 2167730616 phone: +90 505 7958124, +90 2167730616 
expressions of that language. Therefore, for effective and healthy communication, it is important that idioms should be learned or taught correctly in teaching Turkish as a foreign language. This study aims to determine the ways in which idiom teaching can be effective and permanent with supplementary worksheets presented to students in the field of teaching Turkish as a foreign language. The visuals aimed at guessing and concretizing the idioms were used in the worksheets and then explained in the text along with its story. The story of the idioms is taken from the book 'İki Dirhem Bir Çekirdek' by İskender Pala. Based on expert opinions, worksheets were developed on only nine of the 100 idioms in the book. Document analysis method was used in this study. It was determined at the end of the study that using activities and preparing supplementary worksheets would provide more effective and permanent learning of idioms. It is one of the findings that the learning continues not only in the classroom but also in daily life and outside the school. The active participation of the students in the process is a necessity for language learning. The findings of the current study would help to contribute ongoing literature in teaching Turkish to foreigners.

Keywords: Teaching Turkish as a foreign language, idioms, supplementary worksheets

\section{Giriş}

Yabancı dil olarak Türkçe öğretimi son yllarda önem kazanan bir alan haline gelmiştir. Bu alan içerisinde dil öğretimine dair kelime öğretimi, atasözü öğretimi, deyim öğretimi, kültür aktarımı vb. çalışmalar yapılmaktadır. Deyim öğretimi yapılırken hem dört temel dil becerisi hem kültür aktarımı gibi çoklu eğitim stratejileri uygulanmaktadır.

"Deyimler asıl anlamlarından uzaklaşarak yeni kavramlar meydana getiren kalıplaşmış sözlerdir. İki veya daha çok kelimeden kurulu bir çeşit dil ifadesi olan bu sözler duygu ve düşüncelerimizi, dikkati çekecek biçimde anlatan isim, sıfat, zarf, basit ve birleşik fiil görünüşlü gramer unsurlarıdır" (Elçin, 1986: 642).

Deyimler içerisinde asıl anlamlarını koruyan grubun yanında asıl anlamından uzaklaşarak karşılaştığımız deyimler de bulunmaktadır. Genellikle -mek/-mak mastar ekini alırlar ve özlü anlatıma sahiptirler. Deyimlerin atasözlerinden ayrılan yönü de çoğunluğunun mastar şeklinde olmasıdır.

"Deyimler de ulusal damga taşıyan dil varlıklarıdır. Ulusun söz yaratma gücünden doğar. Her deyim hoş bir buluştur. Bir küȩük söz dağarcı̆̆ına koca bir anlam sığdırılmıştır “(Aksoy, 1983: 47).

Kısa kalıplarla yoğun bir anlama sahiptirler. Az sözle dilimize dair gelenek, görenek, kültürel değerler vb. gibi pek çok ögeye rastlama olanağımız vardır. Kalıp sözler hâlinde karşımıza çıktıkları için kelimelerin yerleri değiştirilemez ya da bir sözcüğün yerine başka bir sözcük getirilemez.

Yabancı dil olarak Türkçe öğretimi alanında deyimlerin öğretilmesindeki asıl amaç bu deyimlerin yerli yerinde ve anlamına uygun bir şekilde kullanılmasıdır. Dilimiz açısından büyük öneme sahip olan deyimlerin bir diğer özelliği de her deyimin kendine ait bir hikâyesinin bulunmasıdır.

Aksan, (2000: 82)'a göre bir dilin söz varlığının önemli bir bölümünü oluşturdukları ve çeşitli özelliklerini yansıttıkları için deyimler öğrenilmedikçe, "dil öğrenimi çabası eksik kalır”, dolayısıyla, “dile iyice egemen olabilmek için deyimlerin öğrenilmesi ve bilinmesi gerekmektedir”.

\begin{tabular}{r|l} 
Adres & Address \\
RumeliDE Dil ve Edebiyat Araşttrmalar Dergisi & RumeliDE Journal of Language and Literature Studies \\
Osmanağa Mahallesi, Mürver Çiçeği Sokak, No:14/8 & Osmanağa Mahallesi, Mürver Çiçeği Sokak, No:14/8 \\
Kadıköy - İSTANBUL / TÜRKIYY 34714 & Kadıköy - ISTANBUL / TURKEY 34714 \\
e-posta: editor@rumelide.com & e-mail: editor@rumelide.com, \\
phone: +90 505 7958124, +90 216773 o 616
\end{tabular}


Sağlıklı bir iletişimin gerçekleşmesi ve öğrenilen dilin kurallarına uygun olarak konuşulmasında deyimler hayati bir önem taşımaktadır. Deyimlerin hikâyeleri ile işlenmesi yukarıda da belirtildiği gibi ve buna dair yönlendirici soruların sorulması bireyin okuma, yazma, kara verme, analiz, sentez vb. pek çok üst düzey öğrenme yollarına hizmet edecektir. Bu çalışmada deyimler görsellerle tahmin ettirilmeye çalışılmış ve ardından deyimin hikâyesi işlenmiştir. Çalışmaya esin kaynağı olan deyimler günümüzün Divan Edebiyatı sanatçısı İskender Pala'nın ‘İki Dirhem Bir Çekirdek' kitabından alınmıştır. Deyime ait hikâye anlatıldıktan sonra deyimle ilgili sorular metnin bağlamına uygun olacak şekilde hazırlanmıştır. Hazırlanan sorular açık uçlu, çoktan seçmeli, var-yok, doğru-yanlış, evet-hayır, olumsuz köklü maddelerden seçilmiştir. Çalışmada dilimizin üretici becerilerine hitap etmesi için de bireylere deyimleri cümle içinde kullanma, deyime ait bir olayı anlatma gibi etkinlikler sunulmuştur. Deyimlerin bu şekilde ek çalışma kâ̆̆gtları ile öğretilmesi kalıcı izli öğrenmeleri gerçekleştirmelerine, öğrenilenlerin tekrarı ve pekiştirilmesine hizmet etmesi açısından önemlidir. Bundan sonra yapılacak dil öğretimi çalışmalarına bir örnek teşkil etmesi, çalışmanın gerekliliğini ortaya koymaktadır.

\section{Araştırmanın amacı}

Araştırmanın amacı 'Yabancı Dil Olarak Türkçe Öğretimi' alanında deyim öğretiminin daha kahıcı ve etkili nasıl yapılması gerektiği sorusuna cevap bulmak, ek çalışma kâğıtları ile deyim öğretimini bağlama uygun bir şekilde gerçekleştirmede nelere dikkat edilmesi gerektiğini göstermektir.

\section{Araştırmanın önemi}

Deyimler dilimizin sözlü iletişim varlıklarıdır; mecaz ve gerçek anlam olmak üzere iki grupta sinıflandırılmaktadır. Bu da deyim öğretimi konusunda birtakım problemlere yol açmaktadır. Dil öğrenen bireyler sadece o dilin gramer yapısını değil kullanım alanlarını da öğrenmek zorundadırlar. Günlük hayatta karşılarına çıkan kalıp sözü anlamlandıramazlarsa sağlıklı bir iletişim gerçekleşmez. Bu sebeple deyimlerin öğretimi bu alan için önemlidir. Deyim öğretiminin tek başına değil de metin içerisinde, deyimlere yönelik sorulara cevap verilerek ve öğrencilerin aktif katılımı ile gerçekleşmesine olanak tanıyan ek çalışma kağıtlarına dayanması önemlidir. Özellikle deyim öğretimi sürecinde ek çalışma kâğıtlarının kullanılması bireylerin okul dışı öğrenmelerine hizmet edebilir. Öğrenme ortamını günlük hayata taşıyarak sınıf dışında çalışmaların yapılması açısından da üzerinde durulması gereken diğer bir konudur.

\section{Araştırmanın problem cümlesi}

Yabancı dil olarak Türkçe öğretimi alanında ek çalışma kâğıtları ile deyimler nasıl öğretilmelidir? Bu problem cümlesinin alt problemleri şunlardır:

a. Yabancı dil olarak Türkçe alanında deyim öğretimi hazırlanan ek kağıtlar aracılığıyla nasıl yapılmalıdir?

b. Yabancı dil olarak Türkçe alanında ek kağıtlarla deyim öğretiminin öğrencilere dil becerileri bağlamında faydaları nelerdir?

\section{Araştırmanın yöntemi}

Araştırmada nitel araştırma desenlerinden doküman incelemesi yöntemi kullanılmıştır. "Doküman incelemesi, araştırılması hedeflenen olgu ya da olgular hakkında bilgi içeren yazılı materyallerin analizini kapsamaktadır. Doküman incelemesi, bir araştırma problemi hakkında belirli zaman dilimi

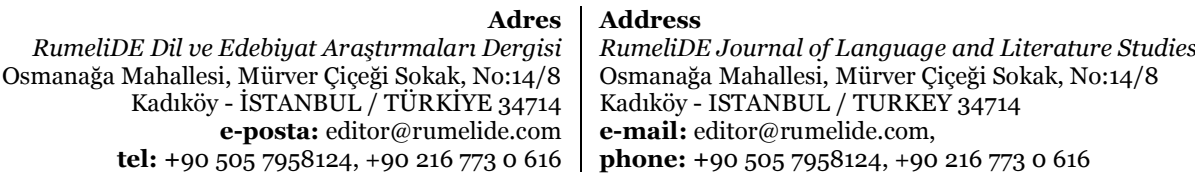


içerisinde üretilen dokümanlar ya da ilgili konuda birden fazla kaynak tarafından ve değişik aralıklarla üretilmiş dokümanların geniş bir zaman dilimine dayalı analizini olanaklı kılmaktadır” (Yıldırım ve Şimşek 2002: 140-143).

\section{Araştırmanın uygulama boyutu}

Yabancı dil olarak Türkçe öğretimi alanında deyim öğretimine yönelik ek çalışma kâğıtlarının belirlenmesinde kullanılan ana kaynak İskender Pala'nın İki Dirhem Bir Çekirdek adlı kitabında yer alan deyimlerdir. İlgili kaynakta yer alan 100 deyimden araştırma amaç ve problemiyle en uyumlu olanların seçimi için Miles-Huberman modelinde genel aşamaları olan verilerin azaltılması, verilerin sunulması ve sonuçların biçimlendirilmesi (Baltacı, 2017: 15-27) takip edilmiştir. İlgili kaynağın iç tutarılığını sağlamak için alan uzmanı üç akademisyenin görüş birliği dikkate alınarak 100 deyimden 9 tanesi yabancı dil olarak Türkçe alanında deyim öğretiminde kullanılabilecek ek çalışma kâğıdı olarak belirlenerek tasarlanmıştır.

Araştırmanın temel kaynağını da oluşturan yabancı dil olarak Türkçe öğretiminde kullanılacak ek çalışma kâğıtlarıyla ilgili iç tutarlılığı sağlamak için Miles ve Huberman modelinde içsel tutarlılık olarak adlandırılan ve kodlayıcılar arasındaki görüş birliği dikkate alınmıştır. $\Delta=C \div(\mathrm{C}+\vartheta) \times 100$ formülü kullanılarak yapılan hesaplamada ilgili kaynağın güvenirlik katsayını da belirleyen içsel tutarlılığı veren kodlama denetimine göre ilgili konuda uzman üç akademisyenin (kodlayıcılar arası görüş birliği) \%88 olarak belirlenmesi (Miles ve Huberman, 1994) ilgili kaynağın içsel tutarlı̆̆ının yeterli olduğunu göstermektedir. Çünkü ilgili alan yazına göre içsel tutarlılığı veren kodlama denetimine göre kodlayıcılar arası görüş birliğinin en az \%80 olması beklenmektedir (Patton, 2002).

\section{Sinırlılıklar}

İskender Pala'nın 'İki Dirhem Bir Çekirdek' kitabında yer alan 100 deyimden alan uzmanlarından alınan görüş birliği sonucunda belirlenen 9 deyimin hikâyesine yönelik ek çalışma kağıtlarıyla sinırlandırılmıştır.

\section{Bulgular ve yorum}

\section{Ek çalışma kâğıtları ile deyim öğretimi}

Deyim öğretimini daha etkili hâle getirmek için sınıf dışında tekrar amaçlı ek çalışma kâ̆ğıtları öğrencilere verilerek sınıfta öğrenilenlerin pekiştirilmesi amaçlanmıştır.

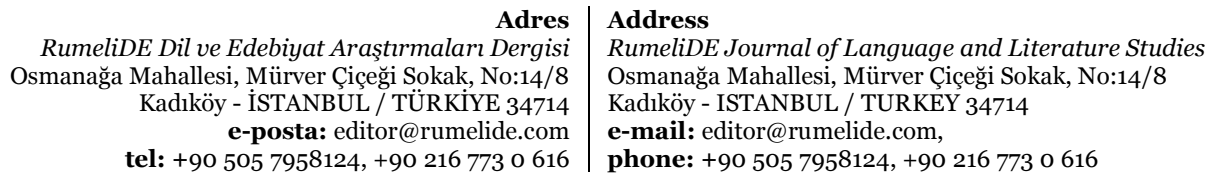

tel: +90 505 7958124, +90 2167730616 


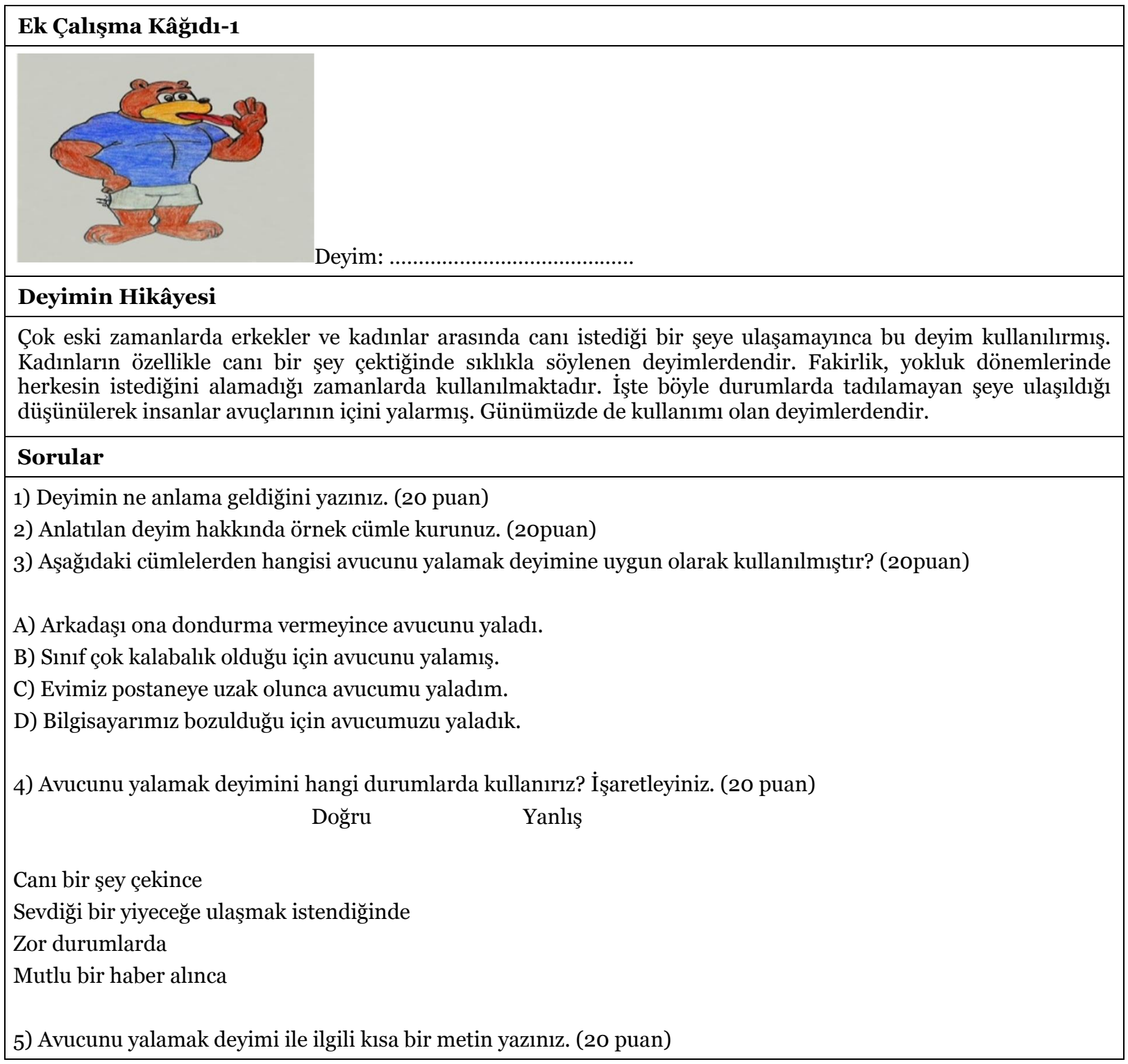

Şekil 1: Ek Çalışma Kâğıdı-1

Çalışma kâğıdı-1'de 'avucunu yalamak' deyimi görsel olarak öğrenciye tahmin ettirilmek istenmiştir. Görselden hareketle bu deyimi tahmin eden öğrenciye deyimin ne anlama geldiği kendi hikâyesi ile anlatılmıştır. Öğrenci seviyesine uygun sorular aracılı̆̆ıla öğrencinin deyimi anlayıp anlamadığı kontrol edilebilir. Açık uçlu, çoktan seçmeli, doğru-yanlış şeklinde farklı soru kökleri kullanılarak deyim öğretiminin daha verimli olması sağlanabilir. Aynı zamanda öğrencilerin yazma, okuma, özgün cümlelerle kendilerini ifade etme vb. beceriler de etkinlik yoluyla geliştirilebilir.

Address

RumeliDE Journal of Language and Literature Studies

Osmanağa Mahallesi, Mürver Çiçeği Sokak, No:14/8

Kadıköy - ISTANBUL / TURKEY 34714

e-mail: editor@rumelide.com,

phone: +90 5057958124, +90 216773 o 616 


\begin{tabular}{|c|c|}
\hline Ek Çalışma Kâğıdı-2 & \\
\hline Deyim:... & 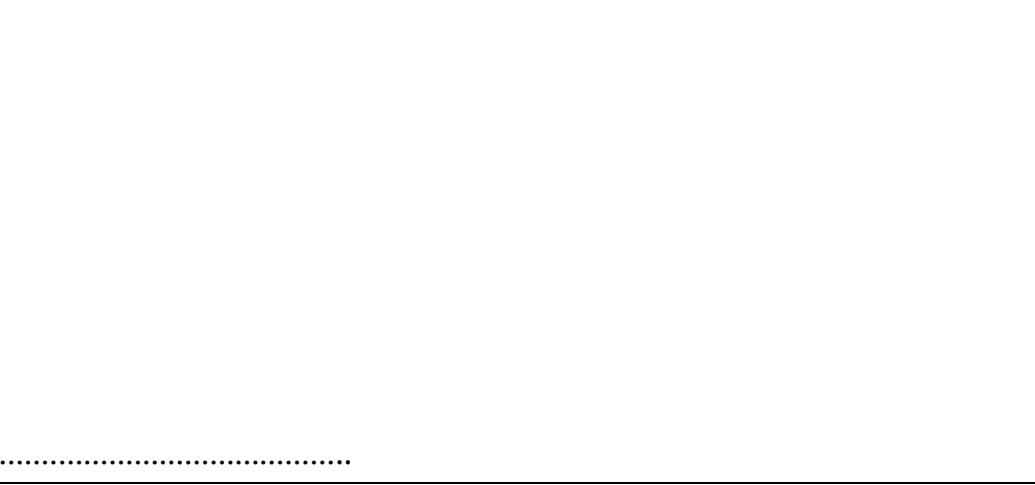 \\
\hline Deyimin Hikâyesi & \\
\hline $\begin{array}{l}\text { Bir konuda birisine güvenmek anlamı } \\
\text { tasavvufta kullanılır. Tarikata yeni gele } \\
\text { giren kişiler bundan sonra tarikatın bi } \\
\text { ulaşacağını düşünür. Günümüzde ise b } \\
\text { bildiren hallerde karşımıza çımaktadı }\end{array}$ & $\begin{array}{l}\text { da kullanılır. O kişiye güvenerek bireyler ümitsizlik beslemezler. Özellikle } \\
\text { a bireylere kemer şeklinde bellerine bir nesne (kuşak) bağlanır. Bu tarikata } \\
\text { ün emirlerine uyar, yasaklarından kaçnmaya çalışır. Bu şekilde de huzura } \\
\text { d anlamından uzaklaşmıştır. Olumsuz durumlar için kullanılır. Güvensizlik }\end{array}$ \\
\hline Sorular & \\
\hline 1) Bel bağlamak deyiminin anlamı ned & n değişmiş̧tir? (25 puan) \\
\hline 2) Deyimi günümüzdeki anlamı ile kul & anınız. (25puan) \\
\hline 3) Aşağıdaki soruları deyime uygun bir & şekilde yantlayını. (25 puan) \\
\hline Evet & Hayır \\
\hline a) Deyimin kullanım alanı zamanla dę̌ & işmiştir. \\
\hline b) Birisine güvenildiği zamanlarda kul & anilır. \\
\hline c) Güvensizlik bildiren hallerde tercih & dilir. \\
\hline d) Öğrenilmesi karışık durumlarda kar & imıza çıkar. \\
\hline 4) Aşağıdaki cümlelerden hangisi deyiı & in anlamına uygun olarak kullanılmamıştır? (25 puan) \\
\hline $\begin{array}{l}\text { A) Yapacağın işte kimseye bel bağlama } \\
\text { B) Bel bağlayacak kimse kalmadı mı? } \\
\text { C) Bu devirde kimseye bel bağlanmaz. } \\
\text { D) Pantolonun ölçüsü için bel bağladı. }\end{array}$ & \\
\hline
\end{tabular}

Şekil 1: Ek Çalışma Kâğıdı-2

Ek çalışma kâğğı-2'de bel bağlamak deyimi görsellerle sezdirilmeye çalışılmıştır. Hazırlanan ek çalışma kâğıdı aracılığıyla ilgili deyim açık uçlu, çoktan seçmeli, evet-hayır ve olumsuz soru kökleri ile öğrenciye sorulup kavratılabilir. Deyimin günümüzdeki ve önceden kullanılan anlamı arasındaki farkların öğrenciye buldurulması öğrencinin kavrama basamağına uygun kazanımlara sahip olduğunu test etmeye yöneliktir.

\begin{tabular}{|c|c|}
\hline Adres & Address \\
\hline turmalar Dergisi & RumeliDE Journal of Language and Literature Studies \\
\hline manağa Mal & Osmanağa Mahallesi, Mürver Çiçeği Sokak, No:14/8 \\
\hline $\begin{array}{r}\text { Kadıöy - ISTANBUL / TÜRKIYY } 34714 \\
\text { e-posta: editor@rumelide.com } \\
\text { tel: +90 } 5057958124,+90216773 \text { o } 616\end{array}$ & $\begin{array}{l}\text { Kadıköy - ISTANBUL / TURKEY } 34714 \\
\text { e-mail: editor@rumelide.com, } \\
\text { phone: +90 505 7958124, +90 } 216773 \text { o } 616\end{array}$ \\
\hline
\end{tabular}




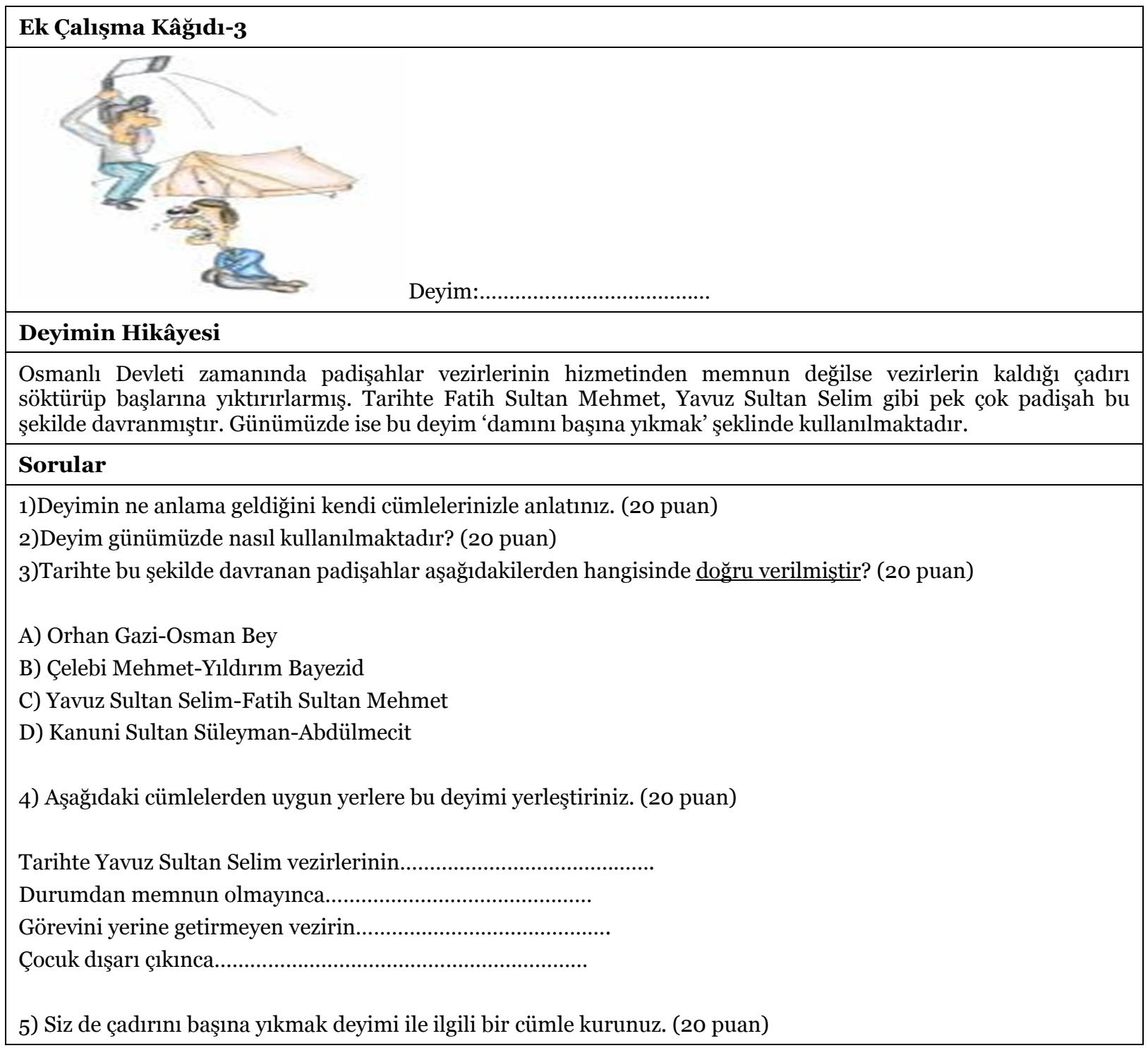

Şekil 3: Ek Çalışma Kâ̆ğdı-3

Ek çalışma kâğıdı-3’te deyim görsel ile öğrencilere tahmin ettirilmeye çalışılabilir. Hazırlanan sorularda deyimin anlamı buldurmaya yönelik etkinlikler mevcuttur. Bu şekilde hem deyim öğretimi hem de kültürel aktarım unsurlarıyla öğrencilerin karşılaşması sağlanabilir. Deyimin hikâyesinden hareketle Türkçeyi öğrenen bir birey Osmanlı Devleti padişahlarını, yönetim şeklini, ülke yönetiminde önem verilen değerleri de öğrenebilir. Ayrıca öğrencilere yöneltilecek sorular öğrencinin düşünme yeteneğini, karar verme, seçim yapma vb. üst düzey düşünme becerilerinin gelişimine katkılar sunabilir. 


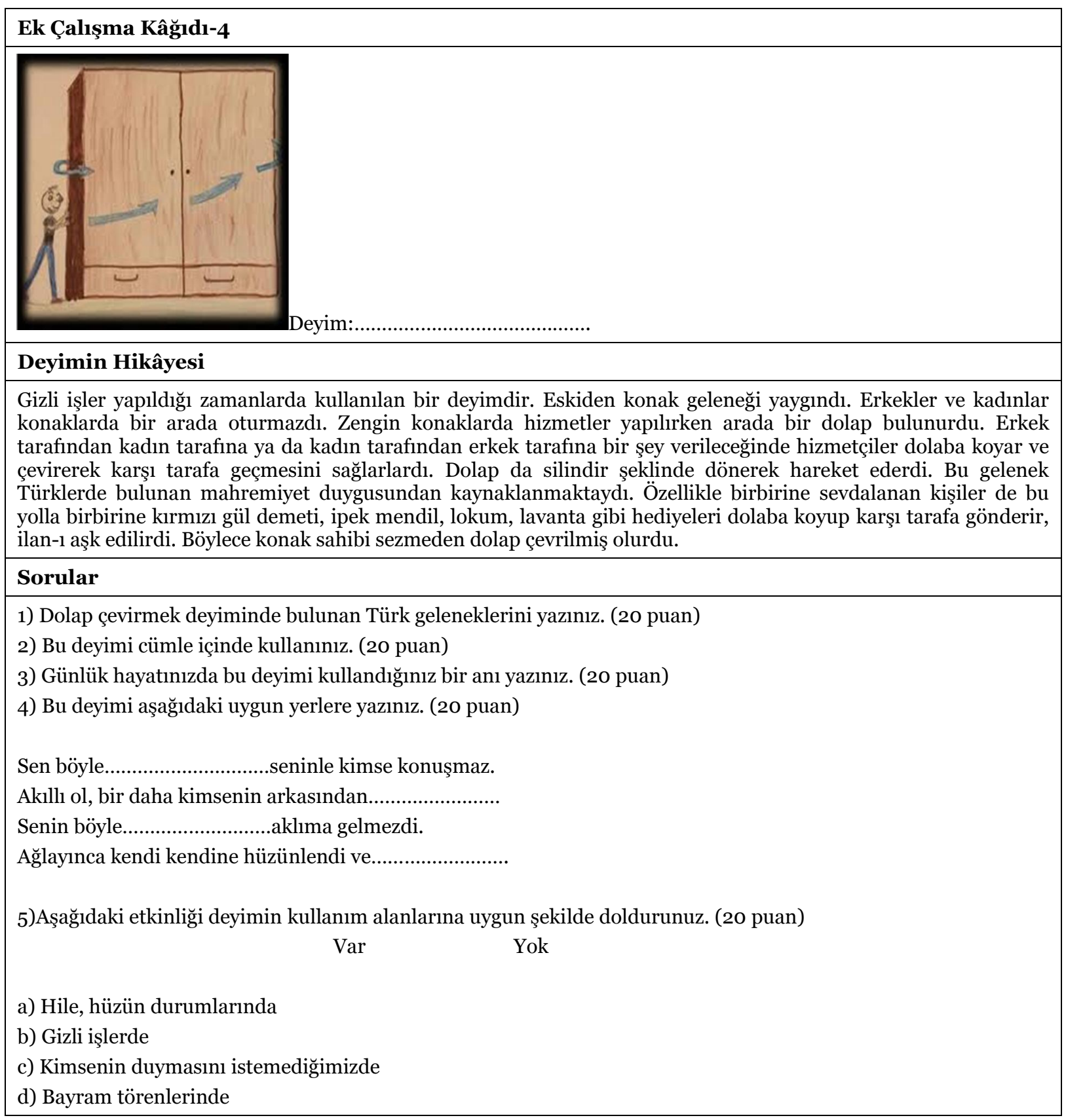

Şekil 4: Ek Çalışma Kâğıdı-4

Ek çalışma kâğıdı-4’te deyimin anlamını verilen görselle birlikte öğrenciye tahmin ettirme amaçlanmıştır. Anlatılan hikâye ile eski Türk gelenekleri, yaşam tarzı vb. değerler karşımıza çıkmaktadır. Öğrencilere yöneltilecek sorularla deyimin kullanım alanı, bağlam içerisinde karşımıza nasıl çıktığını öğrencilerin daha iyi anlamaları sağlanabilir.

Address

RumeliDE Journal of Language and Literature Studies

Osmanağa Mahallesi, Mürver Çiçeği Sokak, No:14/8

Kadıköy - ISTANBUL / TURKEY 34714

e-mail: editor@rumelide.com,

phone: +90 5057958124, +90 2167730616 


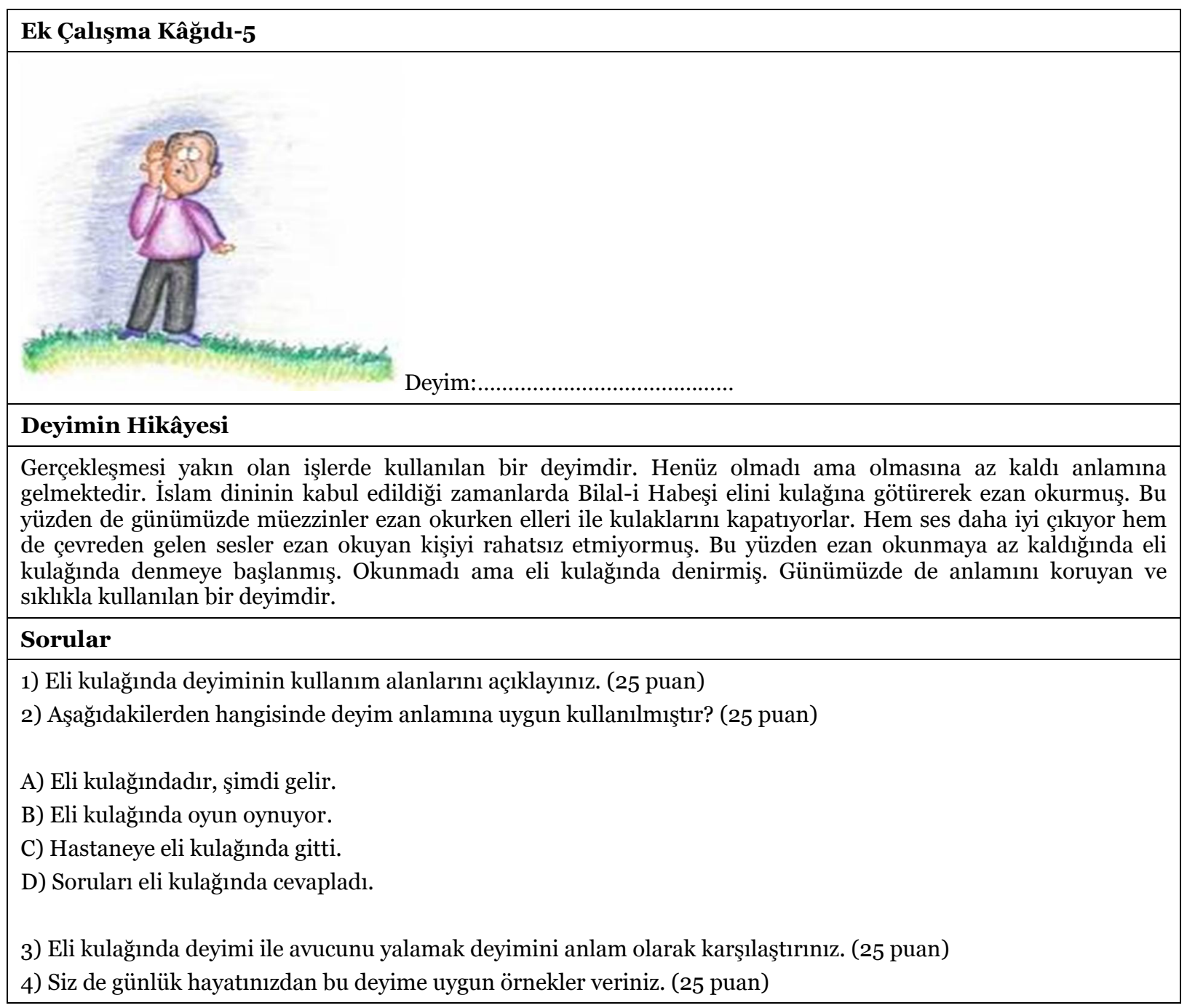

Şekil 5: Ek Çalışma Kâğıdı-5

Ek çalışma kâğıdı-5’te görsel ile verilen bir deyimin anlamı hikâyesi ile öğretilmeye çalışılmıştır. Sorularda öğrencilerin okuma, yazma becerilerini ölçmeye yönelik etkinlikler mevcuttur. Aynı zamanda bilinenden bilinmeyene ilkesi gereği öğrencilerin öğrendiği bir deyimi diğerleriyle ilişkilendirme becerileri de geliştirilebilir. Öğrencilerin kendi yaşamından örnek vermeye çalışması deyimi aktif bir şekilde kullanmasına yardımcı olabilir. Kültür aktarımı açısından Türklerin ezana duyduğu saygı, İslam dinini önemi vb. unsurların metin bağlamından hareketle öğrencilere sezdirilmesi mümkündür. 


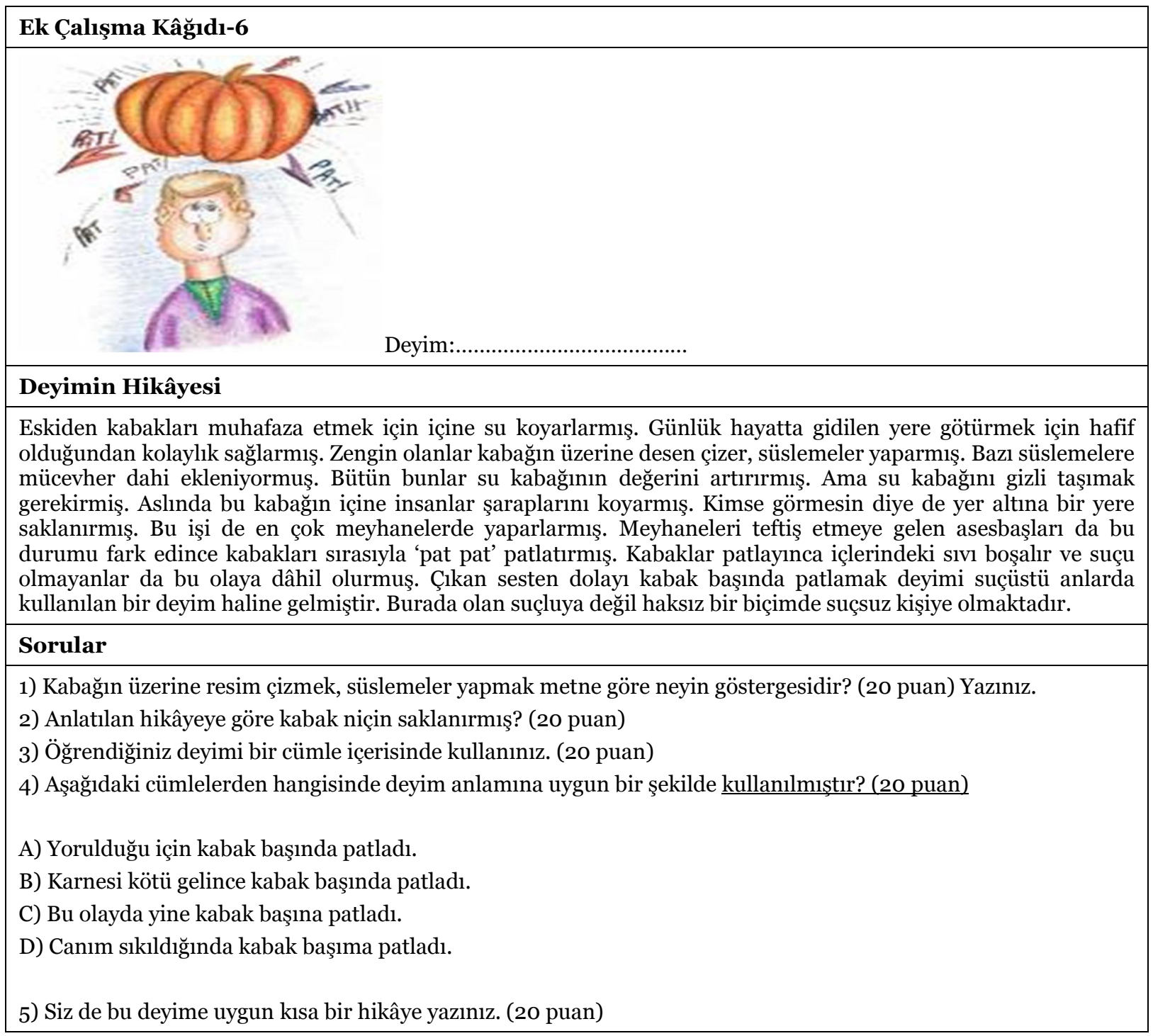

Şekil 6. Ek Çalışma Kâğıdı-6

Ek çalışma kâğıdı-6'da deyim hikâyesi ile verilmiş daha sonra da hatırlama, anlama, kavrama, sentez basamağını yansıtacak sorular ile deyimin öğrenilip öğrenilmediği kontrol edilebilir. Ayrıca deyim hakkında bir resim verilerek tahmin ettirmeye yönelik etkinlik önerisi öğrencilerin zihinsel becerileri geliştirilebilir. Çalışma kâğıdında okuma ve yazma becerilerine yönelik sorular yanında; açık uçlu, çoktan seçmeli madde köklerine yer verilerek öğrencilerin deyimi birçok açıdan kavraması sağlanabilir.

\footnotetext{
Adres

RumeliDE Dil ve Edebiyat Araşttrmalar Dergisi Osmanağa Mahallesi, Mürver Çiçeği Sokak, No:14/8 Kadıköy - İSTANBUL / TÜRKIYE 34714 e-posta: editor@rumelide.com tel: +90 $5057958124,+902167730616$

Address

RumeliDE Journal of Language and Literature Studies Osmanağa Mahallesi, Mürver Çiçeği Sokak, No:14/8

Kadıköy - ISTANBUL / TURKEY 34714

e-mail: editor@rumelide.com,

phone: +90 5057958124 , +90 2167730616
} 


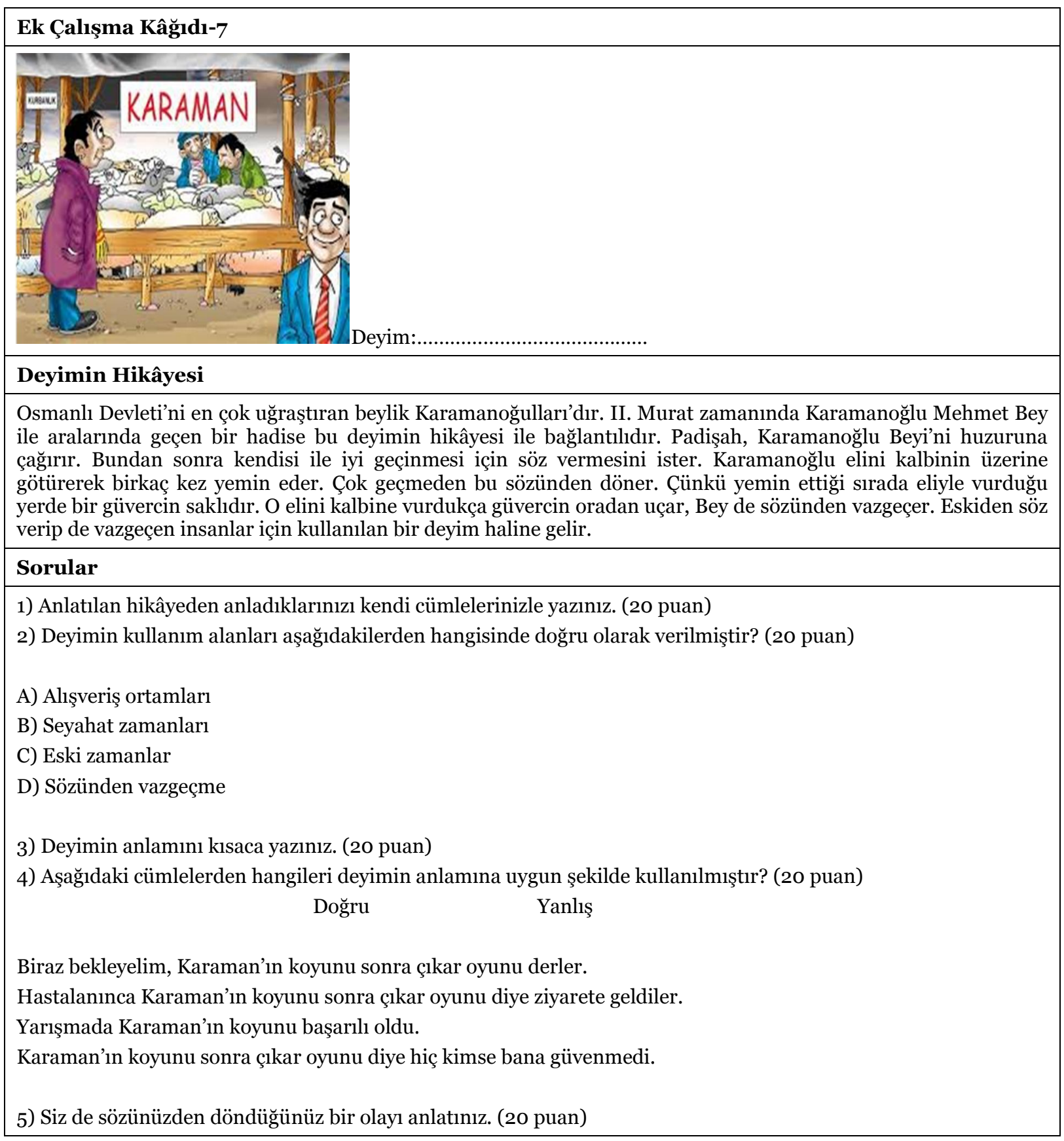

Şekil 7: Ek Çalışma Kâğıdı-7

Ek çalışma kâğıdı-7'de anlatılmak istenen deyim bir görsel ile tahmin ettirilmeye çalışlarak öğrencinin ön bilgileri ve hazırbulunuşluk seviyesi harekete geçirilebilir. Deyimin bu şekilde öğretimi öğrencide dikkat uyandırabilir. Hazırlanan açık uçlu, çoktan seçmeli ve doğru-yanlış madde kökleri ile deyim öğretimi pekiştirilmeye çalışllabilir. Öğrencilerin üretici dil becerilerini harekete geçirilmesi için kendi başlarından geçen bir olayı deyime uygun şekilde anlatması istenebilir. Aynı zamanda deyimin hangi bağlamda kullanıldığına dair sorular da yöneltilerek deyimin birçok açıdan öğrencilerce kavranması sağlanabilir. Osmanağa Mahallesi, Mürver Çiçeği Sokak, No:14/8 Kadıköy - İSTANBUL / TÜRKIYE 34714 e-posta: editor@rumelide.com tel: +90 $5057958124,+902167730616$
Address

RumeliDE Journal of Language and Literature Studies

Osmanağa Mahallesi, Mürver Çiçeği Sokak, No:14/8

Kadıköy - ISTANBUL / TURKEY 34714

e-mail: editor@rumelide.com,

phone: +90 5057958124, +90 216773 o 616 


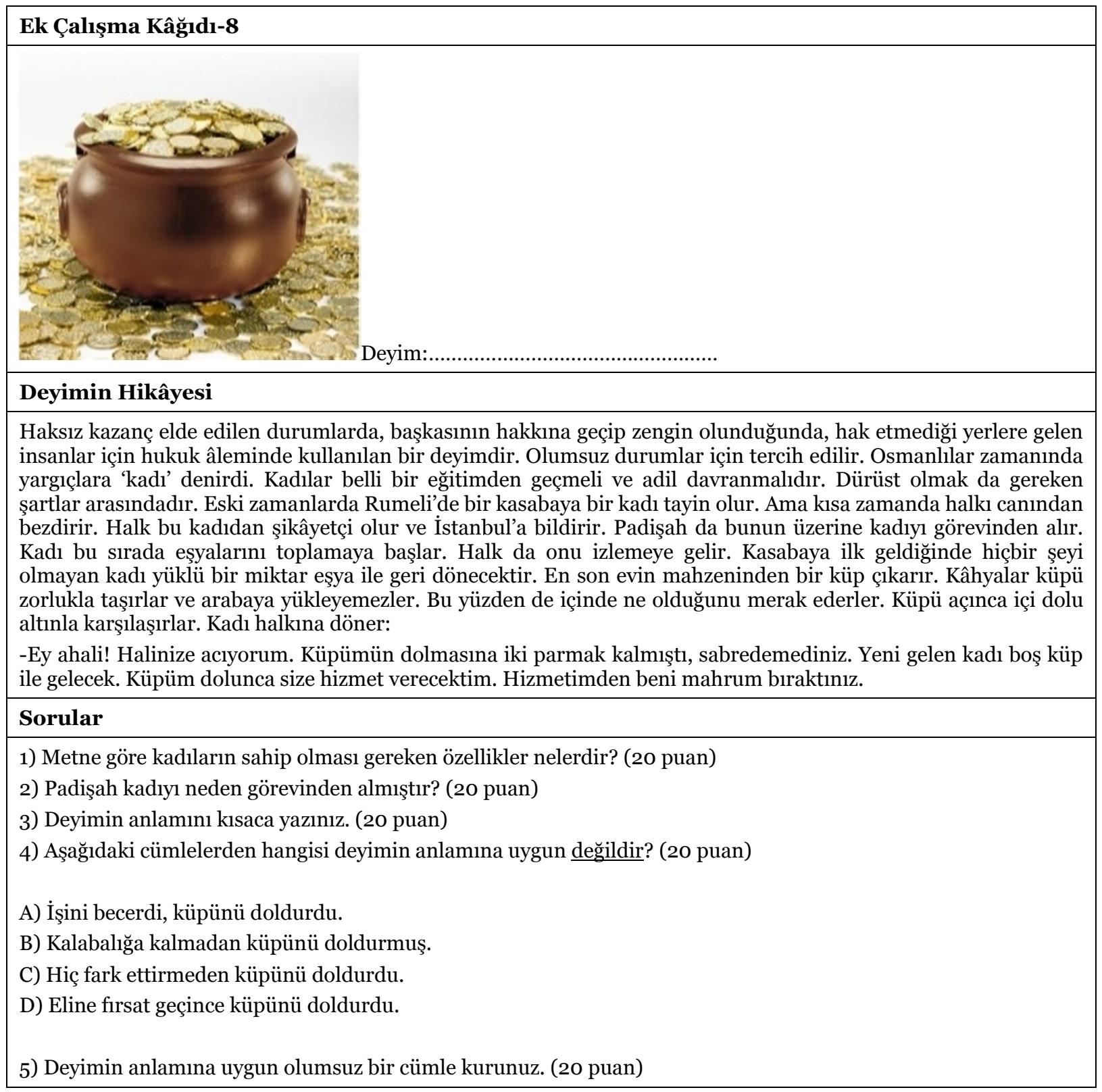

Şekil 8: Ek Çalışma Kâğıdı-8

Ek çalışma kâğıdı-8'de deyimin anlamına ilişkin sorular sorularak öğrencilerin metnin bağlamından hareketle deyimin hikayesini ne kadar anladıkları sorgulanabilir. Olumsuz soru kökleri kullanılarak ve olumsuz yapıda cümle örnekleri kullanılarak öğrencilerin analiz etme becerisi geliştirilebilir. 


\begin{tabular}{|c|}
\hline Ek Çalışma Kâğıdı-9 \\
\hline $\int_{0}$ \\
\hline Deyimin Hikâyesi \\
\hline $\begin{array}{l}\text { Uzun yllar eğitim görmüş kişilere mürekkep yalamış derler. Bu deyim matbaa olmadan önce sik kullanılan bir } \\
\text { deyimdir. El yazması eserlerin olduğu dönemde kullanılırdı. El yazması eserler yazlırken mürekkebi silecek bir } \\
\text { silgi yokmuş. Hattatlar yanlışlarını silecek vakit serçe parmaklarının ucunu yalar ve yanlışı silermiş. Bu şekilde } \\
\text { mürekkep yalamış olurlarmış. Eskiden bir insan ne kadar çok mürekkep yalarsa o derecede bilgili, okumuş, } \\
\text { kültürlü kabul edilirmişs. Toplum da ayrıca bu insanlara saygı duyarmış. Günümüzde de hala kullanılan bir } \\
\text { deyimdir. }\end{array}$ \\
\hline Sorular \\
\hline $\begin{array}{l}\text { 1) Bu deyim hangi alanlarda kullanılır? (25 puan) } \\
\text { Var }\end{array}$ \\
\hline $\begin{array}{l}\text { Okumuş kişiler için } \\
\text { Bilgili insanlar için } \\
\text { Matbaanın olmadığı zamanlarda } \\
\text { Zor durumlarda }\end{array}$ \\
\hline $\begin{array}{l}\text { 2) Sizin de çevrenizde böyle insanlar var mı? Anlatınız. ( } 25 \text { puan) } \\
\text { 3) Deyimin ne anlama geldiğini yazınız. ( } 25 \text { puan) } \\
\text { 4) Siz de deyimi cümle içinde kullanınız. ( } 25 \text { puan) }\end{array}$ \\
\hline
\end{tabular}

Şekil 9: Ek Çalışma Kâğıdı-9

Ek çalışma kâğıdı-9'da metnin bağlamına yönelik sorular sorulmuştur. Diğer çalışma kâğıtlarında olduğu gibi tahmin ettirme, yazma, okuma, seçenekler arasında ayrım yapma vb. bilişsel ve üretici beceriler geliştirilmeye çalışılmıştır. Açık uçlu, var-yok şeklinde madde kökleri kullanılarak deyim öğretilmeye çalışılmıştır.

\begin{tabular}{|c|c|}
\hline Adres & Address \\
\hline turmalar Dergisi & RumeliDE Journal of Language and Literature Studies \\
\hline manağa Ma & Osmanağa Mahallesi, Mürver Çiçeği Sokak, No:14/8 \\
\hline $\begin{array}{r}\text { Kadıöy - ISTANBUL / TÜRKIYY } 34714 \\
\text { e-posta: editor@rumelide.com } \\
\text { tel: +90 } 5057958124,+90216773 \text { o } 616\end{array}$ & $\begin{array}{l}\text { Kadıköy - ISTANBUL / TURKEY } 34714 \\
\text { e-mail: editor@rumelide.com, } \\
\text { phone: +90 505 7958124, +90 } 216773 \text { o } 616\end{array}$ \\
\hline
\end{tabular}




\section{Sonuç, tartışma ve öneriler}

"Bir ulusun yaşayış biçimi, inançları, gelenekleri, dünya görüşü, çeşitli nitelikleri ve hatta tarih boyunca bu toplumda meydana gelen çeşitli olaylar üzerinde hiçbir bilgimiz olmasa, yalnızca dil bilim incelemeleriyle, bu dilin sözvarlığının, söz hazinesinin derinliğine inerek bütün bu konularda çok değerli bilgiler ve güvenilir ipuçları edinebiliriz" (Aksan, 2009: 65). Türkçe, söz varlığı olarak diğer diller ile karşılaştırıldığında çok zengin bir altyapıya sahiptir. Türkçenin bu zenginliğinden ana dili olarak Türkçe öğretiminde yararlanıldığı gibi yabancılara Türkçe öğretiminde de yararlanılmalıdır.

Yabancılara Türkçe öğretiminde söz varlığı konusunda yapılan çalışmalarda; genellikle kitap inceleme, incelenen kitapları karşılaştırma, deneysel çalışmalara rastlanmaktadır. Açık ve Akpınar'ın (2010) çalışmalarında Avrupa Dil Gelişim Dosyası Bağlamında, Yabancılara Türkçe Öğretiminde Deyim ve Atasözlerinin Öğrenme- Öğretme Sürecine Aktarımı incelenmiş ve sonucunda yazılı ve sözlü iletişimde atasözlerinin taranması gerektiği, bulgularının da bu alanda kullanılması zorunluluğuna kanaat getirilmiştir. Gün ve İkizçınar'ın (2019) çalışmasında ise bazı kitaplarda bir söz öbeğinin deyim olmadığ hareketle yabancılara Türkçe öğretimi alanında deyimlere ilişkin çalışmalar bulunsa da konuyla ilgili daha fazla çalışmaya ihtiyaç duyulduğu söylenebilir.

Koparıcı'nın (2019) çalışmasında nitel araştırma yöntemlerinden betimsel tarama ve içerik analizi kullanılmıştır. Deyim gibi geniş söz varlığı içeren bir kavramın diğer söz gruplarından ayrı değerlendirilmesi gerektiği; bu konuda kaynak, materyal, sözlük gibi eksiklerin olduğu tespit edilmiştir. Ayrıca bu çalışmada Diller İçin Avrupa Ortak Öneriler Çerçevesi'nin temel aldı̆̆ı eylem odaklı yaklaşıma göre deyimlerin öğretimi yapılması gerektiği ve bu şekilde daha etkili olduğu sonucuna ulaşılmıştır. Öğrencilerin sürece daha aktif katılım sağlayacakları da bulgular arasındadır. $\mathrm{Bu}$ araştırmadaki bulgu ve öneriler bu çalışmaya başlanmasında etkili olmuş, yabancılara Türkçe öğretiminde ek çalışma kă̆ıtlarından nasıl yararlanılabileceği ve ek çalışma kağıtlarıyla deyim öğretiminin öğrencilerin dil becerilerini nasıl etkileyeceği araştırılmaya başlanmıştır.

Mutlu'nun (2016) “Yabancllara Türkçe Öğretiminde Benzer Atasözü ve Deyimlerin Önemi ve Polonyalılara Türkçe Öğretiminde Bunların Kullanımı” başlıklı çalışmasında Türkçe ile lehçe arasında benzerlik olduğu tespit edilen öğrencilerden derlenmiş 60’ı atasözü, 140’ı da deyim olmak üzere 200 tane atasözü ve deyim sınıflandırılmıştır. Bu tasnif "Kelime/Yapı ve Anlam Benzerliği Olan Atasözleri ve Deyimler" ile "Yalnızca Anlam Benzerliği Olan Atasözleri ve Deyimler" şeklinde yapılmıştır. Özellikle hedef dil ve ana dil arasındaki benzerlikler ölçüt alınmıştır. Araştırma sonucunda ise Türkçe ve Lehçe arasında yapı ve anlamca benzer atasözü ve deyimlerin sayısının özgün olanlara göre daha fazla olduğu görülmüştür. Fakat cümle şeklinde olan ve öğüt veren kelime benzerliği açısından atasözü ve deyim sayılarının az olduğu tespit edilmiştir. Bu araştırma sonuçları ise yurt dışında yaşayanlara Türkçe öğretiminde deyim ve atasözlerinden nasıl yararlanılabileceğini göstermesi açısından önemli olduğu ve bu çalışmayla ilintili olduğu ifade edilebilir.

Alan yazındaki çalışmalar dikkatle incelendiğinde yabancılara Türkçe öğretiminde deyimlerin daha çok sıklık analizlerinin yapıldığı, kitaplarda kullanım özellikleri üzerinde durulduğu, eylem odaklı çalışmalar ile deyimlerden yabancılara Türkçe öğretiminde daha çok yararlanılması gerektiğinin önerildiği görülmektedir. Koparıı'nın (2019) çalışmasında dikkat çekildiği gibi deyim gibi geniş söz varlığı içeren ve diğer söz gruplarından ayrı değerlendirilmesi gereken doğal bir dil kaynağından bu alanda nasıl yararlanılabileceğini örneklemek için hazırlanan bu çalışmada ise uzman görüşleriyle

\footnotetext{
Adres | Address

RumeliDE Dil ve Edebiyat Araşttrmaları Dergisi $\quad$ RumeliDE Journal of Language and Literature Studies Osmanağa Mahallesi, Mürver Çiçeği Sokak, No:14/8 Osmanağa Mahallesi, Mürver Çiçeği Sokak, No:14/8 Kadıköy - İSTANBUL / TÜRKIYE 34714 Kadıköy - ISTANBUL / TURKEY 34714 e-posta: editor@rumelide.com e-mail: editor@rumelide.com, tel: +90 505 7958124, +90 2167730616 phone: +90 505 7958124, +90 2167730616
} 
hazırlanan ek çalışma kağıtları aracıllğıyla deyimlerden derslerde nasıl yararlanılabileceği gösterilmeye çalışılmıştır. Yabancılara Türkçe öğretiminde kullanılabilecek ek çalışma kağıtlarının bulgular kısmında da üzerinde durulup açıklandığı gibi kullanılmasıyla Gipe'nin (1978) çalışmasında belirtildiği gibi Türkçeyi yabancı dil olarak öğrenen öğrencilerin Türkçe kelimelerin anlamı üzerinde düşünmesi sağlanabilir. Yeni kelimelerle; cümle tamamlama, kelimeleri eş anlamlılarıyla eşleştirme, eş anlam ve zit anlam için sözlük kullanma gibi birçok yol denenebilir. Böylece öğrencilerin özellikle üretici dil becerileri olan yazma ve konuşma becerileri daha verimli bir şekilde geliştirilebilir. Ayrıca Tekin ve Baş’ın (2019) çalışmalarının sonuç bölümünde önerildiği ve bu çalışmada da uygulama örneklerine yer verildiği gibi; anlamı çözmeye yönelik stratejilerde ağırlıklı olarak eşleştirme yapma alt stratejisi ile öğrencilerden deyimlerin anlamlarını bulmalarının istenmesi öğrencilerin seçenekler arasında hem eleme yapabilme hem de sözlüğe bakmadan anlamı bulabilme becerilerini geliştirebilir.

\section{Tespit edilen bulgular bağlamında şu önerilerde bulunulabilir:}

- Ders kitaplarında materyal olarak ünite sonu değerlendirme kapsamında ek çalışma kâğıtlarının kullanılması öğrencilerin anlama ve anlatma becerilerini geliştirebilir.

- Görsel materyaller ile birleştirilen deyim hikâyeleri dinleme, okuma, yazma ve konuşma becerilerini geliştirmek için alternatif bir ölçme aracı olarak yabancılara Türkçe öğretiminde değerlendirilebilir.

- Deyimlerin günlük dilde kullanımını daha fazla sağlayacak benzer ders dışı uygulama çalışmalarıyla (proje çalışmaları, drama uygulamaları vb.) öğrencilerin sürece aktif katılımı sağlanabilir.

- Deyimlerin geçtiği şarkı, afiş, metin vb. öğrencilere hem derslerde hem de ders dışı çeşitli etkinliklerle buldurularak öğrencilerin seçici dinleme, seçici okuma vb. becerileri geliştirilebilir.

- Atasözleri, ikilemeler vb. diğer kalıp sözlere yönelik benzer çalışmalar yapılarak yabancılara Türkçe öğretimine yönelik daha fazla materyal ve etkinlik tasarımı yapılabilir.

\section{Kaynakça}

Açık, F. \& Akpınar, M. (2010). III. Uluslararası Dünya Dili Türkçe Sempozyumu, Dokuz Eylül Üniversitesi, İzmir.

Aksan, D. (2000). Her Yönüyle Dil: Ana Çizgileriyle Dilbilim. Ankara: TDK.

Aksan, D. (2009) Her Yönüyle Dil. Ankara: TDK.

Aksoy, Ö. A. (1983). Atasözleri ve Deyimler Sözlüğü. İstanbul.

Baltaci, A. (2017). A Comparison of Syrian Migrant Students in Turkey and Germany: Entrepreneurial Tendencies and Career Expectations. European Journal of Educational Research, 6(1), 15-27. doi:10.12973/eu-jer.6.1.15

Bulut, M. (2013). Türkçe Eğitimi ve Öğretiminde Dil ve Kültür Aktarımı Aracı Olarak Atasözü ve Deyimlerin Önemi. Turkish Studies.8.13.564.

Dinçel Keray, B. ve Savur, H. (2019). Yabancılara Türkçe Deyim ve Atasözü Öğretiminde Kullanılabilecek Bir Araç: Tarkan Şarkıları, International Journal of Language Academy Volume 7/1 March 2019 p. 39/55.

Elçin, Ş. (1986). Halk Edebiyatına Giriş. Ankara: Sevinç.

\begin{tabular}{|c|c|}
\hline & \\
\hline eliDE Dil ve Edebiyat Araşttrmaları De & E Journal of Language and Literature Studies \\
\hline 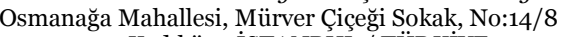 & Mahallesi, Mürver Çiçeği Sokak, No:14/8 \\
\hline Kadıköy $-\mathrm{I}$ & ISTANBUL / TURKEY 34714 \\
\hline $\begin{array}{r}\text { e-posta: editor } \\
\text { tel: }+905057958124,+9\end{array}$ & $\begin{array}{l}\text { editor@rumelide.com, } \\
\text { +90 505 7958124, +90 } 2167730616\end{array}$ \\
\hline
\end{tabular}


Erten Dalak, H. D. (2017). Yabancı dil olarak Türkçe öğretiminde iletişimsel yaklaşımın deyim öğretimindeki başarıya etkisi (Master's thesis, Türkiyat Araştırmaları Enstitüsü).

Gipe, Joan P. (1978). Investigating techniques for teaching word meanings. Reading Research Quarterly. 624-644.

Göçer, A. (2009). Türkçe Eğitiminde Öğrencilerin Söz Varlığını Geliştirme Etkinlikleri ve Sözlük Kullanımı Sözlük Özel Sayısı. Turkish Studies, 4(4), 1025-1055.

Gün, M. \& İkizçınar, B. (2019). Yabancı Dil Olarak Türkçe Öğretiminde Kullanılan Ders Kitaplarındaki Okuma Metinlerinde Atasözü ve Deyimlerin Dağılımı Yedi İklim Örneği. International Journal of Language Academy, 7(3), 214-233.

Koparıcı, I. F. (2019). Yabancı Dil Olarak Türkçe B1 Seviyesinde Deyim Öğretimi/ Öğrenimi, Yüksek Lisans Tezi, Ankara.

Miles, M, B., \& Huberman, A. M. (1994). Qualitative data analysis: An expanded Sourcebook. (2nd ed). Thousand Oaks, CA: Sage.

Mutlu, K. (2016). Yabancllara Türkçe Öğretiminde Benzer Atasözü ve Deyimlerin Önemi Ve Polonyalılara Türkçe Öğretiminde Bunların Kullanımı, Belleten, 64-2, 245-268

Pala, İ. (2014). İki Dirhem Bir Çekirdek, İstanbul: Kapı.

Patton, M.Q. (2002). Qualitative research and evaluation methods (3rd Ed.). London: Sage Publications.

Tekin, E. ve Baş, B. (2019). Yabancı Dil Olarak Türkçe Öğretimi Kitaplarında Atasözü ve Deyimlerin Öğretim Stratejileri, Dil Eğitimi ve Araştırmaları Dergisi, 5(2), 157-171

Yıldırım, A. \& Şimşek, H. (2002). Sosyal Bilimlerde Nitel Araştırma Yöntemleri, Ankara: Seçkin.

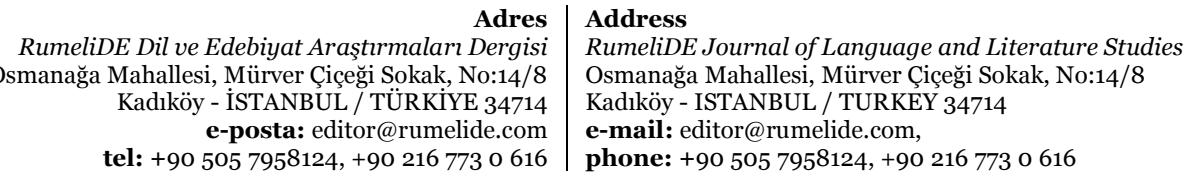

